\title{
Cultivars of early soybeans subjected to cross-sowing in sowing populations
}

\section{Cultivares de soja precoce submetidas à semeadura cruzada em populações de semeadura}

\section{José Mateus Kondo SANTINI ${ }^{*}$; Flávio de Oliveira SILVEIRA ${ }^{2}$; Salatiér BUZETTI ${ }^{3}$; Adriano PERIN ${ }^{4}$; Leonnardo Cruvinel FURQUIM ${ }^{5}$; Daniel Noe COAGUILA Nunez ${ }^{6}$; Luiz Cesar Lopes Filho ${ }^{7}$}

\author{
${ }^{1}$ Autor para correspondência; Engenheiro Agrônomo, Dr., Professor do Instituto de Ensino Superior de Rio Verde; \\ santini@faculdadeobjetivo.com.br \\ ${ }^{2}$ Engenheiro Agrônomo, Consultor técnico da empresa Exacta; exacta.ai@gmail.com \\ ${ }^{3}$ Engenheiro Agrônomo, Dr., Professor da Universidade Estadual Paulista - Faculdade de Engenharia de Ilha Solteira; \\ sbuzetti@agr.feis.unesp.br \\ ${ }^{4}$ Engenheiro Agrônomo, Dr., Professor do Instituto Federal Goiano - Câmpus Rio Verde; perinrj@yahoo.com.br \\ ${ }^{5}$ Engenheiro Agrônomo, Me. Professor do Instituto de Ensino Superior de Rio Verde; \\ leonnardo.cruvinel@faculdadeobjetivo.com.br \\ ${ }^{6}$ Biólogo, Dr., Professor do Instituto de Ensino Superior de Rio Verde; tuheraldo@gmail.com \\ ${ }^{7}$ Engenheiro Agrônomo, Me., Professor do Instituto de Ensino Superior de Rio Verde; lopesfilholuizcesar@gmail.com
}

\section{Recebido em: 29-06-2017; Aceito em: 14-11-2017}

\begin{abstract}
Cross sowing is a little studied technique which may contribute to increase productivity. The objective of this study is to evaluate the effects of cross-sowing on population arrangements of early soybean cultivars with different growth habits. The experiment was completely randomized in a $2 \times 3+2$ factorial design with two cultivars, three cross-sowing populations and two controls (one for each cultivar evaluated, row sowing with 400 thousand plants ha $^{-1}$ ). The experiment was conducted in Rio Verde, Goiás (GO) state. We observed that only the cultivar BMX Potência RR differed from the control as for grain yield. The cultivars responded differently to populations. The BMX Potência RR was more productive in the smallest population and the NA 7337 RR had the highest yield in the larger population. Therefore, the growth habit and sowing population have a direct influence on soybean yield in cross-sowing.
\end{abstract}

Additional keywords: Glycine $\max ($ L.) Merrill; growth habits; seeding density, spatial arrangement.

\section{Resumo}

A semeadura cruzada consiste em técnica pouco estudada, e que pode contribuir para aumento de produtividade. O objetivo do trabalho foi avaliar o efeito da semeadura cruzada em arranjos populacionais, em cultivares de soja precoce de hábitos de crescimento distintos. O experimento foi conduzido em Rio Verde - GO, em delineamento inteiramente casualizado, em fatorial $2 \times 3+2$, sendo: duas cultivares, três populações em semeadura cruzada e duas testemunhas (uma para cada cultivar avaliada; semeadura em linha com 400 mil plantas ha-1). Observou-se que apenas a cultivar BMX Potência RR diferiu da testemunha na produtividade de grãos. As cultivares responderam diferentemente às populações, com a BMX Potência RR, sendo mais produtivas na menor população e a NA 7337 RR com maior produtividade na maior população. Portanto, o hábito de crescimento e a população de semeadura têm influência direta na produtividade de soja, em semeadura cruzada.

Palavras-chave adicionais: arranjo espacial; densidade de semeadura; Glycine max (L.) Merrill, hábitos de crescimento.

\section{Introduction}

Soy is one of the main crops of the world's and the Brazilian economy. In Brazil, it is estimated that, for the $2017 / 18$ crop, soybeans should occupy up to $35,339,200$ ha, accounting for approximately $59.3 \%$ of the total cultivated area of grains, with a production of 108,639,800 Mg (CONAB, 2017). Grains are used by agribusiness (vegetable oil and food for animals), chemical and food industries, and recently as biofuel (Bergman et al, 2013).
In order to increase productivity, soybean farmers have sought the evolution of their farms with regard to both the use of new technologies and management systems, the advent of transgenic cultivars and genetic improvement. However, new soybean varieties, with growth habits and sizes different from the first lineages used in Brazil, require changes both in plant arrangement and spacing (Ferreira et al., 2017).

A technique that has been mentioned and considered for soybeans as promising in increasing 
productivity is cross-sowing (commonly referred to by farmers as "Cross-planting"). This technique consists of sowing part of the population in rows and part in perpendicular, that is, crossing them forming a "chess table" (Procópio et al., 2013). This technique, although little studied, has been considered of great value, appearing in the First Edition of the National Challenge of Maximum Productivity of soybean crops (referring to the $2009 / 10$ crop) carried out by CESB (Soja Brazil Strategic Committee), where a grain yield of $6,504 \mathrm{~kg}$ $\mathrm{ha}^{-1}$ was recorded. In the same way, a productivity of $6.522 \mathrm{~kg} \mathrm{ha}^{-1}$ was obtained in the Third Edition, creating speculations about the real effectiveness of this technique.

Population is a determining factor for the arrangement of plants in the production environment, influencing soybean growth and productivity. In this sense, an adequate plant population must provide, in addition to a high agricultural productivity, adequate stacking and harvesting conditions (Gaudêncio et al., 1990). However, data on populations are contradictory; some studies show no effects on grain yield (Balbinot Junior et al., 2015, Andrade et al., 2016) and other studies show a significant effect on plant populations (Vazquez et al., 2008; Rocha et al., 2015). This nonconsensus is because soil and climate conditions exert a direct influence on the response of the plant population, as well as on phytosanitary conditions, genetic material and technologies used (Freitas et al., 2010; Yang et al., 2014; Soares et al., 2015).

In the cross-sowing system, arrangement and populations should be appropriately recommended according to the cultivar and its respective growth habit, directly interfering with grain yield in soybean crops. It is necessary to adapt the different spatial arrangements to the populations in order to obtain their maximum productive. In the scientific literature, information on the cross-sowing system is scarce, requiring studies to evaluate the system seeking to verify its validation and better recommendations in its use.

Thus, the objective of this study is to evaluate the effects of cross-sowing in population arrangements on early soybean cultivars with different growth habits in order to estimate their effects on grain production and yield components.

\section{Material and methods}

The experiment was conducted in the field between 10-29-2011 and 03-24-2012 in Rio Verde, southwest of the state of Goiás, located at 17\%48'30" S and $50^{\circ} 54^{\prime} 17^{\prime \prime} \mathrm{W}$, at an altitude of $748 \mathrm{~m}$, in a soil classified as Dystroferric Red Latosol (EMBRAPA, 2013). Fertility and soil particle size analyses were performed, showing the following results: $\mathrm{pH}$ (in water $)=6.0, \mathrm{P}$ (Mehlich $\mathrm{I})=19 \mathrm{mg} \mathrm{dm}^{-3}, \mathrm{~K}=$ $=6.7 \mathrm{mmol}_{\mathrm{cm}} \mathrm{dm}^{-3} \mathrm{Ca}=47 \mathrm{mmol}_{\mathrm{c}} \mathrm{dm}^{-3}, \mathrm{Mg}=$ $=22 \mathrm{mmol}_{\mathrm{c}} \mathrm{dm}^{-3}, \mathrm{Al}=0.0 \mathrm{mmol}_{\mathrm{c}} \mathrm{dm}^{-3}, \mathrm{H}+\mathrm{Al}=$ $=66.0 \mathrm{mmol}_{\mathrm{c}} \mathrm{dm}^{-3}$, BS $=77 \mathrm{mmol}_{\mathrm{c}} \mathrm{dm}^{-3}, \mathrm{CEC}=$ $=123 \mathrm{mmol}_{\mathrm{c}} \mathrm{dm}^{-3}, \mathrm{~V} \%=60$, and medium texture
(331 $\mathrm{g} \mathrm{kg}^{-1}$ of clay, $167 \mathrm{~g} \mathrm{~kg}^{-1}$ of silt and $502 \mathrm{~g} \mathrm{~kg}^{-1}$ of sand).

The experimental design was completely randomized in a $2 \times 3+2$ factorial design. Two cultivars with different growth habits (BMX Potência RR and NA $7337 \mathrm{RR})$ were evaluated. There were three crosssowing populations (350, 400 and 500 thousand plants per hectare) and another two control treatments, one for each cultivar, adopting sowing in rows with a population of 400 thousand plants per hectare (recommended population). Despite understanding the need to isolate external factors, as all sowings were performed with the same machinery, the possible population corrections were not performed, and only the final populations were verified at the end of the study.

The cultivar NA 7337 RR has a semi-determined growth habit with an early cycle (115 days), recommended for sowing in a population of 320-450 thousand plants per hectare for the region. The cultivar BMX Potência RR has an indeterminate growth habit with an early cycle (105 days), recommended for a population of 350-450 thousand plants per hectare for the region.

Before the implementation of the experiment, the area was leveled. The sowing of the cultivars occurred on November 10, 2011, in a mechanized way. Six rows were sown in each plot, spaced $0.45 \mathrm{~m}$, with a length of $6 \mathrm{~m}$; in the treatments with crosssowing, the seeds were sown perpendicular to the plot.

The maintenance fertilization was carried out at the time of sowing with the application of $80 \mathrm{~kg} \mathrm{ha}^{-1}$ of $\mathrm{P}_{2} \mathrm{O}_{5}$ using triple superphosphate and $60 \mathrm{~kg} \mathrm{ha}^{-1}$ of $\mathrm{K}_{2} \mathrm{O}$ using potassium chloride, according to Sousa \& Lobato (2004). The seeds were treated with Carbendazin fungicide and Fipronil insecticide, both at a dosage of $50 \mathrm{~g}$ i.a. for $100 \mathrm{~kg}$ of soybean seeds, and inoculated with the strains Semia 587 and Semia 8079 of the genus Bradyrhizobium japonicum. In all plots, the cultural traits were carried out whenever necessary for the conduction of the crop, such as weed management, pests and diseases, until grain harvest.

Harvesting was performed at 108 days after emergence (DAE) for the cultivar BMX Potência RR and at 119 DAE for the cultivar NA 7337 RR.

The number of pods per plant (NPP) was obtained from the average of five plants at the time of harvest at random. For the evaluations of yield and mass of 1,000 grains, a manual harvesting was done in the useful area of each plot ( $8.8 \mathrm{~m}^{2}$ plants) and trod using a mechanical harvester. The grains were benefited, and the moisture was determined and corrected to $13 \%$. The yield of grains of the useful area was converted into $\mathrm{kg} \mathrm{ha}^{-1}$. After the grains were harvested, the evaluation of the mass of 1,000 grains (M1000) was carried out using an average of four samples.

Data were submitted to analysis of variance by F test $(p<0.05)$ using the Assistat software. Qualitative treatments were compared by Tukey test $(p<0.05)$. 
Dunnett's test $(p<0.05)$ was used to compare controls. Regression analysis was applied to the data concerning the quantitative variable (plant population).

\section{Results and discussions}

The number of pods per plant (NPP) did not differ among cross-sowing populations when compared to the control (row sowing) for both cultivars
(Table 1). The absence of a difference between the treatments can be explained by the reduced population variation of the cross-sowing (350-500 thousand pl ha ${ }^{1}$ ), when compared to the control (400 thousand $\mathrm{pl} \mathrm{ha}^{-1}$ ), and its genotypic response. In spite of this non-effect, it was observed that the value of NPP of the control is very close to that of the crossed population, with 400 thousand $\mathrm{pl}^{\text {. ha }}{ }^{-1}$, further supporting the aforementioned hypothesis.

Table 1 - Number of pods per plant (NPP), mass of 1,000 grains (M1000) and grain yield (Yield) in soybean cultivars submitted to different populations (thousand plants per hectare).

\begin{tabular}{lcccccc}
\hline $\begin{array}{c}\text { Plant Population } \\
\text { (thousands pl. ha-1) }\end{array}$ & NPP & $\begin{array}{c}\text { M1000 } \\
(\mathrm{g})\end{array}$ & $\begin{array}{c}\text { Yield } \\
\left(\mathrm{kg} \mathrm{ha}^{-1}\right)\end{array}$ & NPP & $\begin{array}{c}\text { M1000 } \\
(\mathrm{g})\end{array}$ & $\begin{array}{c}\text { Yield } \\
\left(\mathrm{kg} \mathrm{ha}^{-1}\right)\end{array}$ \\
\hline 500 & 31 & 165 & $2,938 \mathrm{~b}$ & 55 & 159 & 3,836 \\
400 & 41 & 163 & $3,421 \mathrm{a}$ & 50 & 161 & 3,079 \\
350 & 58 & 160 & $3,779 \mathrm{a}$ & 57 & 160 & 3,225 \\
Control & 42 & 166 & $2,707 \mathrm{~b}$ & 46 & 158 & 3,381 \\
\hline CV $(\%)$ & 27.5 & 2.4 & 7.9 & 13.6 & 1.6 & $9.9^{\text {n }}$ \\
\hline F Test & $3.4^{\text {ns }}$ & $1.8^{\text {ns }}$ & $12.2^{*}$ & $2.1^{\text {ns }}$ & $3.1^{\text {ns }}$ & $3.8^{*}$ \\
\hline
\end{tabular}

ns: Not significant $(P>0.05)$; *: Significant $(P \leq 0.05)$. Average values followed by the same lower case letter do not differ at Dunnet's range test $(p>0.05)$.

Kerber (2013) observed similarities in NPP in cross-sowing compared to row sowing for the cultivars BRS Valiosa RR and BMX Potência RR. In a similar way, Ferreira (2013), upon evaluating the cultivars BRS Valiosa and BMX Potência RR, observed that among the populations of 240-360 thousand pl. ha $^{-1}$ sown in row, the NPP differs little from the treatments in a cross-sowing design.

For the mass of 1,000 grains (M1000), no differences were observed among cross-sowing populations compared to the control (row sowing) for both cultivars studied (Table 1). This response is because this characteristic is little influenced by external factors, being related to the cultivar genotype (Figueiredo \& Vieira, 1970). Results close to those obtained for M1000, in relation to sowing density, are easily found in the literature, both for row sowing (Heiffig et al., 2006; Mauad et al., 2010) and cross-sowing (Ferreira, 2013; Kerber, 2013).

In relation to grain yield, the populations of 350 and 400 thousand pl. ha ${ }^{-1}$, using cross-sowing, of the cultivar BMX Potência RR were higher than the control (400 thousand pl. ha-1 in row sowing) (Table 1). The cultivar NA 7337 RR did not differ compared to the different populations of the cross-sowing and the control (row sowing). This contrast in the behavior between both cultivars is due to the different growth habits. The cultivar BMX Potência RR has an undetermined growth, while NA 7337 RR has a semi-determined growth. Thus, the BMX Potência RR has a better spatial arrangement, obtaining a greater use of the area, but only for the populations of 350 and 400 thousand $\mathrm{pl}$. ha- ${ }^{-1}$, not becoming viable for a population of
500 thousand pl. ha-1 ${ }^{-1}$ However, this result differs from that obtained by Procópio et al. (2013), who did not observe a difference in soybean yields between crosssowing and row sowing for undetermined growth cultivars.

Among the cultivars studied, differences were observed for number of pods per plant and mass of 1,000 grains (Table 2). This difference is due to the genotypic characteristics of the cultivars. Although the BMX Potência RR has a lower number of pods per plant, it has a higher grain mass. This may therefore justify the non-occurrence of a productivity difference. In a study by Rocha et al. (2012) comparing soybean cultivars, it was observed that grain mass varies among cultivars. Likewise, Aquino et al. (2011) observed an average difference among eight cultivars tested for grain mass, and the number of pods per plant may vary according to the cultivar.

There was a decreasing linear fit among populations studied for cross-sowing (Table 2), a result that is commonly found in the literature, where the decrease in NPP occurs due to the increase in the sowing population (Mauad et al., 2010; Ferreira, 2013). Pires et al. (2000) mentioned that studies with variations in the arrangement of soybean plants should take into account the great plasticity, which consists in the capacity of the plant to change its morphology and production components in order to adapt them to the space available and the competitive condition imposed by the arrangement of plants. In high sowing populations, soy reduces NPP (and its production components), and in low populations, such values tend to increase. 
Table 2 - Number of pods per plant (NPP), mass of 1,000 grains (M1000) and grain yield (Yield), of two soybean cultivars submitted to different plant populations.

\begin{tabular}{|c|c|c|c|}
\hline Cultivar & NPP & $\begin{array}{l}\text { M1000 } \\
(\mathrm{g})\end{array}$ & $\begin{array}{c}\text { Yield } \\
\left(\mathrm{kg} \mathrm{ha}^{-1}\right)\end{array}$ \\
\hline BMX Potência RR & 43 & 163 & 3,379 \\
\hline Nidera 7337 RR & 53 & 160 & 3,379 \\
\hline $\begin{array}{l}\text { Plant Population } \\
\text { (thousands pl. ha-1) }^{-1}\end{array}$ & NPP & $\begin{array}{l}\text { M1000 } \\
(\mathrm{g})\end{array}$ & $\begin{array}{c}\text { Yield } \\
\left(\mathrm{kg} \mathrm{ha}^{-1}\right)\end{array}$ \\
\hline 500 & 43 & 162 & 3,386 \\
\hline 400 & 45 & 162 & 3,249 \\
\hline 350 & 57 & 160 & 3,502 \\
\hline CV (\%) & 22.1 & 1.6 & 9.6 \\
\hline \multicolumn{4}{|c|}{ F test } \\
\hline Cultivar (C) & $5.8^{*}$ & $7.3^{* \star}$ & $0.0^{\mathrm{ns}}$ \\
\hline Population (P) & $4.1^{*}$ & $2.1^{\mathrm{ns}}$ & $1.2^{\mathrm{ns}}$ \\
\hline $\mathrm{C} \times \mathrm{P}$ & $2.5^{\mathrm{ns}}$ & 2.9 ns & $11.7^{* *}$ \\
\hline
\end{tabular}

ns: Not significant $(P>0.05)$; : Significant $(P \leq 0.05) ;{ }^{* *}$ : Significant $(P \leq 0.01)$

There was no difference in the mass of 1,000 grains in function of the population studied, which may be explained by the fact that grain mass is an inherent characteristic of each cultivar, that is, it has little variation in the environment (Cunha et al., 2015). That is, changes in grain characteristics are not expected when adequate conditions exist for the development of the crop. Ferreira (2013) found a similar result by performing cross-sowing analyses, noting a difference in grain mass. Mauad et al. (2010), in an evaluation of planting density, did not observe differences for grain mass.

Among the cultivars evaluated, no differences were observed for grain yield. Both had the same agricultural production capacity (Table 2). However, it should be noted that the cultivar BMX Potência RR was harvested at $108 \mathrm{DAE}$ and the NA $7337 \mathrm{RR}$ at 119 DAE. This difference of 11 days is relevant since, in this region, the period for sowing of the second harvest was long. Likewise, no adjustments were observed in grain yield (Table 2). It should be noted that even though there was no positive effects on productivity for the cultivars and the populations under study, the productivity obtained was considered satisfactory since the productivity of the experiment was, on average, $13 \%$ higher than the Brazilian one (CONAB, 2017).

Among cultivars (BMX Potência RR and NA $7337 \mathrm{RR})$ and cross-sowing populations (350, 400 and 500 thousand pl. ha- $\left.{ }^{-1}\right)$, there was a significant interaction with grain yield (Table 3). Uhry (2010) also found a similar result upon evaluating three cultivars and two populations, where there were no significant effects for isolated factors; however, when the interaction was evaluated, they had a significant effect.

Table 3 - Grain yield $\left(\mathrm{kg} \mathrm{ha}^{-1}\right)$, adjustment and coefficient of determination $\left(\mathrm{R}^{2}\right)$, derived from cultivars and plant populations of soybeans in cross-seeding.

\begin{tabular}{lccccc}
\hline \multirow{2}{*}{ Cultivar } & \multicolumn{2}{c}{ Plant population (thousands plants ha (1) $^{*}$} & \multirow{2}{*}{ Adjust } & \multirow{2}{*}{$\mathrm{R}^{2}$} \\
\cline { 2 - 5 } & 350 & 400 & 500 & & \\
\hline BMX Potência RR & $3,779 \mathrm{a}$ & $3,420 \mathrm{a}$ & $2,938 \mathrm{~b}$ & $\hat{\mathrm{Y}}=-5.4986 \mathrm{Pop}+5,670.1$ & 0.9890 \\
NA 7337RR & $3,226 \mathrm{~b}$ & $3,078 \mathrm{a}$ & $3,836 \mathrm{a}$ & $\hat{\mathrm{Y}}=4.5704 \mathrm{Pop}+1,475.5$ & 0.7555 \\
\hline
\end{tabular}

*Average values followed by the same letter in the column do not differ according to Tukey's range test $(p>0.05)$.

It is observed in the populations that both cultivars present different responses (Table 3). The cultivar BMX Potência RR has a linear decrease in grain yield in function of the increase in population, that is, smaller populations (350 thousand pl. ha-1) obtain the highest yields. However, the cultivar NA 7337 RR had a linear increase in grain yield directly proportional to the increase in the population, that is, the largest populations (500 thousand pl. ha- ${ }^{-1}$ ) obtained the highest yields.

Among the cultivars evaluated, there were no differences in the population of 400 thousand pl. ha ${ }^{-1}$. For the other populations, there was a difference between the cultivars, with the cultivar BMX Potência RR being higher in the lowest population
(350 thousand pl. ha- ${ }^{-1}$ ) and NA $7337 \mathrm{RR}$ higher in the largest studied population (500 thousand pl. ha-1) (Table 3). This difference is due to the growth habit of the cultivars. The BMX Potência RR has an undetermined growth and the NA 7337 RR has a semidetermined growth. Thus, the increase in the population of BMX Potência RR, grown in crosssowing, does not become feasible, since its continuous growth, after flowering, causes intra-specific competition, resulting in competition among plants by directing photosynthesis products to height growth and reducing the growth of branches (Mauad et al., 2010), considered as future sources of photoassimilates.

For the cultivar NA 7337 RR, because it has a semi-determined growth, the increase in the population 
in cross-sowing promotes a better use of the area, and there is no disordered increase of ramifications and intra-specific competition. Vazquez et al. (2008) concluded that the increase in sowing density provides higher yields to cultivars with determined growth habits, confirming the plant response of this study. Procópio et al. (2012) observed no differences in soybean grain yield for cultivars with an indeterminate and determined growth habit, respectively, but it should be noted that they were evaluated at different spacings and in two populations. It is worth noting that studies using crosssowing are still lacking, requiring further studies to prove its real efficacy.

\section{Conclusions}

Cross-sowing yields better results when compared to row sowing when adopted for cultivars with an undetermined growth habit (BMX Potência RR) and in populations containing 350 and 400 thousand plants $\mathrm{ha}^{-1}$.

Growth habit has a direct influence on grain yield in cross-sowing. Cultivars with a semi-determined growth habit yield better in high populations, since indeterminate growth habit cultivars have higher yields in smaller populations.

\section{References}

Andrade FR, Nóbrega JCA, Zuffo AM, Junior VPM, Rambo TP, Santos AS (2016) Características agronômicas e produtivas da soja cultivada em plantio convencional e cruzado. Revista de Agricultura 91(1): 81-91.

Aquino LA, Silva TC, Aquino RFBA, Batista $\mathrm{CH}$, Silva HRF (2011) Avaliação agronômica de cultivares de soja sob irrigação no semiárido mineiro. Revista Brasileira de Agricultura Irrigada 5(3):165-172. doi:10.7127/rbai.v5n300055

Balbinot Junior AA, de Oliveira Procópio SO, Costa JM, Kosinski CL, Panison F, Debiasi H, Franchini JC. (2015). Espaçamento reduzido e plantio cruzado associados a diferentes densidades de plantas em soja. Semina: Ciências Agrárias 36(5):2977-2986.

Bergmann JC, Tupinambá DD, Costa OYA, Almeida JRM, Barreto CC, Quirino BF (2013) Biodiesel production in Brazil and alternative biomass feedstocks. Renewable and Sustainable Energy Reviews 21: 411-420.

CONAB (2017) Companhia Nacional de Abastecimento - Acompanhamento de safra brasileira: Grãos, Brasília, 4(2), 2016, 182p.

Cunha RPD, Corrêa MF, Schuch LOB, Oliveira RCD, Junior A, Souza J, Almeida TLD (2015). Different treatments of seeds on the development of soybean plants. Ciência Rural 45(10):1761-1767.
EMBRAPA (2013) Empresa Brasileira de Pesquisa Agropecuária. Sistema brasileiro de classificação de solo. 3. ed. Rio de Janeiro: Centro Nacional de Pesquisa de Solos. $353 \mathrm{p}$.

Ferreira AS, Zucareli C, Baltinot Junior C, Alvadi A, Werner F, Coelho AE (2017) Size, physiological quality, and green seed occurrence influenced by seeding rate in soybeans. Semina: Ciências Agrárias 38(2):595-605.

Ferreira MB (2013) Viabilidade técnica e análise econômica da semeadura cruzada de soja. Unesp (Trabalho de Conclusão de Curso; Graduação em Agronomia)

Figueiredo MS, Vieira, C (1970) Efeito do tamanho das sementes sobre o "stand", produção e altura das plantas, na cultura do feijão (Phaseolus vulgaris L.). Revista Ceres 17(91):47-60.

Freitas MCM, Hamawaki OT, Bueno MR, Marques MC (2010) Época de semeadura e densidade populacional de linhagens de soja UFU de ciclo semitardio. Bioscience Jornal 26(5):698-708.

Gaudêncio C, Gazziero DLP, Jaster F, Garcia A, Wobeto C (1990) População de plantas de soja no sistema de semeadura direta para o centro-sul do Estado do Paraná. Comunicado Técnico do Centro Nacional de Pesquisa de Soja, 47:p.1-4.

Heiffig LS, Camara GMS, Marques LA, Pedroso DB, Piedade SMS (2006) Fechamento e índice de área foliar da cultura da soja em diferentes arranjos espaciais. Bragantia 65(2):285-295. doi:10.1590/S000687052006000200010

Kerber BF (2013) Avaliação do método do plantio cruzado na cultura da soja na região de planaltina-go avaliação do método do plantio cruzado na cultura da soja na região de planaltina-GO. UnB (Trabalho de Conclusão de Curso; Graduação em Agronomia).

Mauda M, Silva TLB, Almeida Neto Al, Abreu VG (2010) Influência da densidade de semeadura sobre características agronômicas na cultura da soja. Revista Agrarian 3(9):175-181

Pires JLF, Costa JA, Thomas AL, Maehler AR (2000) Efeito de populações e espaçamentos sobre o potencial de rendimento da soja durante a ontogenia. Pesquisa Agropecuária Brasileira 35(8):1541-1547. doi:10.1590/S0100-204X2000000800006

Procópio SO, Balbinot Junior AA, Debiasi H, Franchini JC, Panison F (2013) Plantio cruzado na cultura da soja utilizando uma cultivar de hábito de crescimento indeterminado. Revista de Ciências Agrárias 56(4):319-325. doi:10.4322/rca.2013.048 
Rocha RNC, Peluzio JM, Barros HB, Fidelis RR, Silva Junior HP (2015) Comportamento de cultivares de soja em diferentes populações de plantas, em Gurupi, Tocantins. Revista Ceres 48(279):529-537.

Rocha RS, Silva JAL, Neves JA, Sediyama T, Teixeira $R C$ (2012) Desempenho agronômico de variedades e linhagens de soja em condições de baixa latitude em Teresina-PI. Revista Ciência Agronômica 43(1):154162.

Soares IO, Rezende PM, Bruzi AT, Zuffo AM, Zambiazzi EV, Fronza V, Teixeira CM (2015) Interaction between soybean cultivars and seed density. American Journal of Plant Sciences 6(09):14251434.
Sousa DMG, Lobato E (2004) eds. Cerrado: Correção do solo e adubação. Planaltina, Embrapa Cerrados. $416 \mathrm{p}$.

Uhry D (2010) Adubação nitrogenada e densidade de semeadura em soja. 60p. UFSM (Dissertação Mestrado).

Vazquez GH, Carvalho NMD, Borba MMZ (2008) Redução na população de plantas sobre a produtividade e a qualidade fisiológica da semente de soja. Revista Brasileira de Sementes 30(2):1-11. doi:10.1590/S0101-31222008000200001

Yang F, Huang S, Gao R, Liu W, Yong T, Wang X \& Yang W (2014). Growth of soybean seedlings in relay strip intercropping systems in relation to light quantity and red: far-red ratio. Field Crops Research 155:245$-253$. 